\title{
The digital divide at three disadvantaged secondary schools in Gauteng, South Africa
}

\section{Grasia Chisango}

Faculty of Education and School Development, Department of Curriculum Studies, Walter Sisulu University, Queenstown, South Africa

gchisango@wsu.ac.za

https://orcid.org/0000-0002-9951-1120

\section{Newlin Marongwe}

Faculty of Education and School Development, Department of School Improvement Programmes, Walter Sisulu University, Queenstown, South Africa

nmarongwe@wsu.ac.za

https://orcid.org/0000-0002-1354-7107

(Received: 27 February 2020; accepted: 2 February 2021)

\section{Abstract}

In this study, we aimed to explore the extent of the digital divide at three quintile 1 secondary schools in Sedibeng West, Gauteng, South Africa. The rapid diffusion of information and communication technology (ICT) has changed the education sector along with others in societies around the globe. Technology, and, in particular, the internet, has affected, for instance, the ways in which learners communicate with teachers, learn, and work. With the advent of the internet, teaching and learning is no longer confined to classrooms. However, the digital divide, exposed by the closing of schools because of Covid-19 has now become more apparent. We collected data from 48 teachers and 3 school principals through focus group discussions and in-depth face-toface interviews, respectively. We conclude that the three schools whose principals we interviewed, suffer from the inadequacy of ICT that creates digital, information, and knowledge divides between schools of different quintiles. Furthermore, these schools cannot run online classes during school closures related to Covid-19. We recommend training teachers and learners on how to use technology in teaching and learning since this would help to overcome difficulties during the Covid-19 pandemic.

Keywords: digital divide, Covid-19, secondary schools, disadvantaged communities, South Africa 


\section{Introduction}

Information and communication technology (ICT) plays an essential role in political, social, and economic sectors in this information age. There is, therefore, a need for individuals to have adequate ICT skills for them to function effectively in the information society in times of calamity. Schools and universities in South Africa and in the rest of the world are currently faced with the challenges of the Covid-19 pandemic that is necessarily affecting how teaching and learning are conducted. In order to save the 2020 school year, the South African Department of Basic Education instructed schools to use ICT and to adopt online teaching and learning (Motshekga, 2020).

Digital literacies, such as ICT literacy, information literacy, and media literacy have been emphasised as the pillars of 21st century skills (Chen, 2015). The South African government recognises that digital literacies are essential to teachers and learners, and that digital competencies prepare the learner for the world of work in the information age (Department of Education, 2004). The ability to use ICT is an essential competency among teachers and learners since it functions "as an enabler of teaching and learning" (Chen, 2015, p. 2). The use of ICT, such as the internet, extends teaching and learning beyond the classroom. While, on the one hand, the use of mobile technology devices, such as tablets, can promote motivation, sustain conversations, and support seamless learning experiences (Chen, 2015), access to the internet, on the other, allows for greater and fairer use by learners. But, for this to happen, teachers must have adequate access to ICT otherwise they might be forced to resort to traditional teaching and learning methodologies.

In this study, we sought to explore the extent of the digital divide at three secondary schools in Sedibeng West in Gauteng, South Africa.

\section{Literature review}

With the increase in the use of ICT the digital divide, which is defined as "a social inequality between individuals regarding access to ICT, frequency of use of technology, and the ability to use ICT for different purposes" (Ercikan et al., 2018, p. 4), becomes more apparent. The same observation was made by the Deputy Minister of Higher Education, Buti Manamela, who, in noting that a move by schools and institutions of higher learning to online teaching would side-line students from poor backgrounds, said, "No student should be left behind. Students who have no study gadgets or internet connectivity should not be treated as though they were the cause of \#Covid-19" (quoted in Njilo, 2020, para. 4). Manamela feared that in having schools move to online learning, the divide would be deepened, and this would exclude learners and students from disadvantaged backgrounds.

The more the use of ICT has penetrated into the education sector, the more the digital divide can be seen in schools in developing countries (Chen, 2015). This has been worsened by the advent of Covid-19. Individuals who are most excluded from the advantages of advances in ICT are situated in rural areas in developing countries as the president of the University of 
Johannesburg's Student Representative Council (SRC) noted in 2020. In South Africa, the digital divide exists between schools in affluent suburbs and the poorly resourced schools in poor areas (Department of Education, 2004). Although ICT infrastructure, such as access to the internet, tablets, smartboards, computers, and laptops, has been rolled out at some schools in some disadvantaged communities in South Africa, van Dijk (2005, p. 4) postulated that "the digital divide is deepening where it has stopped widening." Having access to ICT infrastructure does not necessarily mean that an individual has ICT skills and/or uses the infrastructure (Chisango et al., 2019). Concurring with Chisango et al. Zhong (2011), has argued that digital divide issues have expanded from ICT access to other issues concerning opportunities to develop the required skills and capabilities to participate. There are three levels of the digital divide in schools: ICT infrastructure; ICT usage by teachers and learners in the classroom; and empowerment of individual learners (Hohlfeld et al., 2008). Factors such as teachers' attitudes towards technologies and their resistance to new ICT hinder the use of technologies in the classroom (Chisango \& Marongwe, 2018; Du Plessis \& Webb, 2012). Our study investigated the extent to which the already existing digital divide has deepened at disadvantaged schools in South Africa during the state of national lockdown in South Africa following the outbreak of the Covid-19 pandemic. Our focus is on van Dijk's (2008) access model that we adopted for this study and that we use to discuss the study findings.

\section{Van Dijk's access model}

Van Dijk's (2008) access model, related to the digital divide, is based on motivational access, material access, skills access, and usage access.

\section{Motivational access}

For an individual to appropriate a technology, s/he has to be motivated to use it. Individuals who believe that ICT is important are most likely to acquire the technology. Those who believe that having ICT is not of importance are less likely to acquire it; van Dijk and Hacker (2003, p. 4) have noted that both the "have-nots" and the "want nots" exist in society.

Surveys conducted in Europe and America between 1999 and 2003 revealed that some of the respondents who were not then connected to the Internet said that they did not like the infrastructure, that having the internet was unimportant, and that some of them lacked ICT skills.

It has been argued that there are psychological factors that affect motivational access. These include social factors, technophobia, and the stress and anxiety experienced when they confront, for example, computers (Spelman \& Marongwe, 2018). Some individuals believe that the internet is for the working class and that it does not appeal to less educated and lowincome individuals (Katz \& Rice, 2002). 


\section{Material access}

Sufficient motivation has been shown to lead an individual to acquire physical access to ICT such as having a computer or a tablet. To have material access means having access to ICT infrastructure and to the cost of the ICT device. Hence, material access is closely related to the socio-economic status of an individual. Individuals who earn a high income are more likely to own more than one device of good quality, whereas those with low incomes most probably own ICT devices that are of poor quality and that sometimes malfunction (van Deursen \& van Dijk, 2018). Furthermore, those with low incomes are most likely to have internet connection on a smartphone only, whereas those with high incomes are most likely to have internet connection on smartphones and other ICT gadgets such as laptops and personal computers (Tsetsi \& Rains, 2017). Students living with high-income parents are more likely to have access to and use ICT at home compared to those whose parents have a low income or none at all (DeBell \& Chapman, 2006). In a bid to close the material access gap, the South African Department of Education developed the Thutong (place of learning) portal in 2005 in order to provide access to online resources to teachers, learners, school managers, and parents (Isaacs, 2007). Teachers and learners can share information on the portal through discussion forums and blogs and they can also upload material.

\section{Skills access}

The availability of ICT does not necessarily mean that an individual uses it since several skills need to be developed for meaningful use of this technology including technology literacy. The creation of ICT knowledge and its deepening must occur for this to happen (UNESCO, 2011). It has been argued that the digital competency of teachers includes the ability to assist learners in becoming collaborators, creators of knowledge, and problemsolvers through using ICT so that they become effective citizens in the information age (UNESCO, 2011). Thus, there is need for continuous ICT training programs to build capacity among them and sufficient training on ICT integration if teachers are to teach effectively in connected classrooms.

Hsu (2010) has argued that a teacher who is well-trained in the use of ICT is most likely to use it in the classroom but those who lack confidence in this area are unlikely to use technology in their teaching (see Chigona \& Chigona, 2010). Benali et al. (2018, p. 99) have observed that some teachers are not yet "good enough at the kind of pedagogies that make the most of technology."

Digital competencies are influenced by several factors such as attitudes towards ICT and contextual factors, like, for instance, curricula requirements (Benali et al., 2018). Teachers' attitudes towards ICT influence their acceptance and use of it in teaching and learning. Studies conducted by Sáncheza et al. (2012), suggested that some teachers who have positive attitudes towards ICT rarely use the technology in teaching. These teachers require more ICT training and adequate ICT infrastructure. 


\section{Usage access}

Internal and external factors influence ICT usage (Shan Fu, 2013). External factors include the availability of ICT infrastructure and its accessibility, technical support, and time to prepare for classes. The frequency of usage and the number and diversity of applications, among other things, affect usage. Internal factors include beliefs and attitudes, motivation to use ICT, ICT skills, and the confidence to use the ICT. For instance, Palak and Walls's (2009) findings revealed that a teacher's attitude towards ICT significantly predicted their ICT use in teaching and learning and, therefore, their learners' use. The more positive a teacher is about ICT, the more likely it is that they will use the technology. In addition, a study conducted by Seraji et al. (2017) revealed that younger teachers were more positive towards ICT use in teaching than were older teachers. Also, the less experienced teachers had a more positive attitude than did the more experienced teachers (Inan \& Lowther, 2010). However, Semerci and Aydın's (2018) findings revealed that there were no significant differences between age and attitudes towards ICT and that there were no significant differences between teaching experience and attitude towards ICT use in teaching and learning among secondary school teachers in Ankara.

\section{Methodology}

We adopted a qualitative research approach since in this study we sought to explore the deepening digital divide at some disadvantaged township secondary schools that were purposively selected for data collection in consultation with the Sedibeng West District Department of Education officials. These three secondary schools are situated in the same local municipality-Emfuleni-which is under Sedibeng West District, in which ICTs such as smartboards, the internet, computer laboratories and /or tablets had been rolled out by the Gauteng Department of Education (GDE) as part of the 2015 rollout since this was our primary selection criterion. ${ }^{1}$ The Gauteng Department of Infrastructure Development (GDID) Member of the Executive Council (MEC) Nandi Mayathula-Khoza stated that providing ICTs to all learners "[would] assure equity to any learner irrespective of their race, class or gender" (South African Government, 2015, para. 7). The roll out of ICT infrastructure was accompanied by training, maintenance, and support (South African Government, 2015).

We adopted a case study design because, following Baxter and Jack (2008), it afforded us opportunities to explore a phenomenon in context using a variety of data sources.

Furthermore, a qualitative case study approach is an effective design for investigating and understanding complex issues in real world settings as Harrison et al. (2017) have reminded us. Also, this approach was valuable to this study aimed at evaluating the adoption and use of ICT and developing interventions on how to bridge the digital divides, because of its flexibility and rigor, especially during the Covid-19 pandemic.

1 This rollout was part of a five-year plan that targeted no-fee schools in townships (SA Government News Agency, 2016). 


\section{The schools}

These schools are in an area that is faced with socio-economic challenges, such as high unemployment rates and lack of access to resources, with most of its inhabitants living below the poverty datum line (Molefe et al., 2018). The three secondary schools are all poorly resourced quintile 1 non fee-paying schools (see van Dyk and White, 2019), that serve impoverished communities, receive funding from the government and at which learners are provided with meals.

School A had 1,431 learners, 50 teachers including the school principal, and 2 deputy heads. There were 2 overhead projectors, 13 smartboards, internet access in the administration block, and an empty computer laboratory. The smartboards were mounted in 7 Grade 11 classrooms and 6 Grade 12 classrooms. Only teachers who taught those grades accessed the smartboards for teaching and learning. It is also important to note that by the time the data was collected, no smartboards were working.

School B had 1,368 learners and 40 teachers, including the school principal and 2 deputy heads. Available ICT infrastructure included an empty MTN ICT laboratory, 10 smartboards and internet access in the administration block. The 10 smartboards were installed in 5 Grade 11 and 5 Grade 12 classrooms. Only 1 smartboard was connected to the internet and the rest were not since the routers had been stolen. Only teachers who taught these grades had access to the smartboards.

School $\mathrm{C}$ had 1,481 learners and 60 teachers, including the school principal and 2 deputy heads. It had 25 dysfunctional computers in the laboratory, 10 smartboards, and 2 overhead projectors. Only 4 Grade 11 classrooms had functional smartboards while the other 3 did not. There were functional smartboards in 4 Grade 12 classrooms and 1 classroom had a dysfunctional smartboard. We were informed that there was another smartboard for a Grade 12 classroom, but it had not been installed by the time this study was conducted.

\section{Data sources and collection}

Our sources of data in this study were teachers and school principals. A purposive sampling technique was used for this study because it helped us to select only participants who were willing to provide rich information and who were experiencing the phenomenon under study. This sampling drew 48 teachers and 3 school principals. We conducted 2 focus group discussions at each of the 3 schools. Each focus group was composed of 8 teachers who were teaching different grades and subjects. The school principals participated in the individual indepth face-to-face interviews.

Data was collected before the outbreak of Covid-19 and we wrote this paper during the lockdown period in April 2020. We used semi-structured focus group discussions and indepth face-to-face interviews to collect data from teachers and school principals, respectively. We organised the semi-structured interviews around the topic, and, in line with the suggestions of O'Keeffe et al. (2016) this helped us lead the conversations in a standardised 
way and simultaneously allow relevant issues to emerge from the discussions. The use of interviews as part of a qualitative case study design allows participants to share their opinions and experiences, in this case, of using ICT in teaching and learning. The collected data was transcribed, organised, coded, and arranged into themes. We use participants' words, that is, verbatim quotations in our presentation of the data.

The van Dijk (2008) model was found to be relevant and suitable for this study, especially given the call that was made to schools to shift their focus to online teaching in South Africa because of the Covid-19 pandemic. As mentioned above, the model focuses on motivation, material, skills, and usage access so we used these categories in analysing the results.

\section{Ethical considerations}

Ethics refers to "the moral principle and guiding conduct . . . held by a group or even a profession" (Wellington, 2015, p. 540). We were given permission by the Gauteng Provincial Department of Education to conduct the research. The anonymity of the participants was observed, and confidentiality maintained. We used codes to identify participants and their schools, instead of using real names. The School Principal of School A is SA, of School B, is $\mathrm{SB}$, and of School C is SC. Focus groups were coded as follows: School A (A1 and A2), School B (B1 and B2) and School C (C1 and C2).

\section{Findings}

Themes related to the problem statement emerged from the research findings. A discussion of these themes is offered below and quotations from the interviews are included in the findings.

\section{Insufficient ICT infrastructure for teaching and learning}

It emerged from the interviews with the three school principals that there was insufficient ICT infrastructure at their schools as Chisango (2019) noted despite the fact that the GDE started rolling out ICT to schools in 2015. According to these principals, online teaching and learning was not really feasible despite the call made by the Gauteng Department of Education. The principals concurred that most learners lacked ICT skills, did not have the tools to manage ICT, had no access to wi-fi, could not afford to buy data, and had network connection problems. It can thus be argued that schools in disadvantaged communities were (and remain) unprepared for the demands occasioned by the Covid-19 pandemic and are therefore not ready to start online classes as compared to some of their urban counterparts.

Principal SA said,

The school used to be on Gauteng online ${ }^{2}$ but is now disconnected. Tablets are only given to Grade 12 learners and all other learners do not [get them]. It is again these

\footnotetext{
2 Gauteng online refers to the Paperless Classroom Project that was initiated in 2015 in a bid to connect all schools
} in the province. 
Grade 12s whose classrooms have smartboards installed in them, so it's only Grade 11 and 12 teachers who use the smartboards.

The other two principals expressed similar views as those shared by SA. Issues of insufficient ICT also surfaced in the focus group interviews. The $\mathrm{C} 2$ teachers revealed that "out of the seven Grade 11 classes at the school, only four classes had smartboards but no tablets or laptops for learners" (see Chisango, 2019, p. 184). Only four Grade 12 classes had smartboards at this particular school. At School A, we found out that no smartboards were working.

A frustrated teacher in B2, who had been given some training, explained,

There was no need to be trained [but] both teachers and learners were not given enough ICT infrastructure to use when teaching.

As was evident in B2 school, insufficient ICT infrastructure hinders the adoption and use of ICT. Both teachers and learners did not have the devices necessary for online classes so this further disadvantages these learners who come from communities where the digital divide has deepened and is continuing to deepen. Teachers, as the actual implementers of digital learning, are faced with the reality of inadequate ICT infrastructure. As indicated by a teacher in B2 school, teachers and learners were not given adequate ICT infrastructure but were expected to implement the online teaching.

\section{Limited internet access}

The interviews with the principals revealed that there was limited internet access at schools. Principal SC explained,

Currently, all the computers in the Gauteng online laboratory are not functioning. The Gauteng online laboratory was switched off by the DoE in 2015. The DoE wants to refurbish the computer laboratory hence switching off the internet.

Teachers echoed the views of the school principals that internet access was confined to only the administration block at schools. Teachers and learners had no access to the internet at home. The teachers from the three schools confirmed and reiterated the points made by the principals. The three schools were no longer connected to Gauteng online. It was revealed that schools were disconnected from it because of the theft of computers and routers (Chisango, 2019). A teacher at C2 said, "Gauteng online is now Gauteng offline." In addition, a teacher at School B (B1) stated,

Tablets are useless in class and worse at home. There is no wi-fi for them to get onto the internet so we can't use them for education purpose when they are in class.

Furthermore, a teacher at A2 pointed out, 
The other challenge is that some teachers are trained but don't implement the acquired skills. Some of the activities that they are trained on use wi-fi. The teachers cannot use such programmes because some learners' tablets are not connected to the internet.

It can thus be said that limited access to the internet compounded by lack of skills prevents some teachers from using ICT during the lockdown period as necessitated by the Covid-19 pandemic. It is clear from the responses above that the digital divide in these schools is deepening even more than before.

\section{Conditions of some of the available ICT infrastructure}

Some teachers revealed that some ICT infrastructural components were not in good working order. Teacher C1 explained,

Sometimes they [smartboards] just freeze. Today I was supposed to use it for my class and I actually prepared over the weekend a very interesting lesson. When I got there it just froze, it just turned on, but nothing was on. It was just quiet. It couldn't talk to me and I wanted to communicate with it.

Additionally, the second focus group at School B revealed that learners' tablets were of poor quality and broke easily. Participants said that only Grade 12 learners were meant to be given tablets for a year and added that the tablets would be collected at the end of each year. However, sometimes learners were not given tablets for the year or even for a term. The first focus group at School C echoed the views expressed by principal SB that "some of the laptops that some Grade 11 teachers were given by the DoE were either not functioning properly or not functioning at all" as Chisango (2019, p. 187) noted later. Therefore, teachers and learners had to resort to the textbooks. Given all this, it is evident that teachers and learners could not turn to online home learning that was considered a nightmare compounded by low internet connections or none at all.

\section{Theft and vandalism of ICT infrastructure at schools}

There was a high rate of theft and vandalism in the communities in which the schools were situated. ICT devices were stolen from schools and homes. According to the principals, security guards at schools were intimidated and tied up by thieves. Principal SA said that "the DoE rolled out computers in the Gauteng online laboratory twice, but all the computers were stolen." The school principals concurred that learners in the community were also robbed of their tablets. Principal SB stated that "since there was no wi-fi at school and at home, learners would go to hotspots at the nearby Evaton Mall where they were robbed of the tablets or laptops." Principal SC pointed out that "some learners' tablets were forcefully taken from them when they were either walking from home to school or from school to their homes or [when they were] at home." These thefts hampered the use of ICT in the classroom and at home. 


\section{Teachers' attitudes towards ICT use in teaching and learning}

It is interesting to note that teachers' views illustrate another common problem that schools in the study were facing. Principal SB posited that some teachers were technophobic, so they avoided all use of the technology. Echoing principal SB's perception, teacher B2 explained,

ICTs came when I [had been] 25 years in the profession. Generally, my mind, my computer, [my] brain is shut towards [the] learning of new skills. They say it's an attitude but basically you know we are people who were born before this technology came. So, it is maybe more preferable that if taken as a transition, the youngsters from the universities, you know, put in those classes with technology and then [we] ... do the chalking in the lower grades where there are no smartboards.

In addition, teacher B2 went on to say,

I was hesitant, unwilling to use it [a smartboard] but because the learners themselves are experienced, they have got the techniques of using the smartboard, [so] you just let them be in front. Make them operate it for you. The teacher will just explain the concept to the learners.

\section{Limited ICT skills among teachers}

It can be deduced from teacher B2's response above that attitude coupled with limited ICT skills might be a hindrance to the adoption and use of instructional technology. Another teacher in B2 School highlighted that "some teachers rely on learners when using technology because they have limited ICT skills." Participants felt uncomfortable talking about the challenge of limited ICT skills since they viewed this as an embarrassing situation. Teachers and school principals all agreed that inadequate ICT skills among teachers was a hindrance to the use of ICT in teaching and learning. Principal SA explained that "some senior teachers were never equipped with ICT skills when they were at university, hence they had limited digital skills." Teachers reiterated that some of them had inadequate ICT skills. Teachers in school $\mathrm{C}$ revealed that their ICT training was not adequate, and they were trained only in basic skills, so, if learners were to write on tablets, they would not know how to mark these assignments. It also became apparent that in school C, only Grades 10 to 12 teachers were trained on how to use ICT in teaching and learning, and the rest of the teachers were not.

\section{Discussion}

The Cooperative Governance and Traditional Affairs (COGTA) Minister Nkosazana Dlamini-Zuma on 25 April 2020 during the briefing session on Risk-Adjustment Strategy for Economic Activity indicated that Covid-19 had exposed the hunger, poverty, unemployment, inequality and so forth that South Africa has been experiencing for a long time. Minister Dlamini-Zuma even made a call for the restructuring of business, education, technologies, and other general ways of doing things. Van der Berg \& Spaull (2020) have argued that the poorest in South Africa have limited to no access at all to ICTs such as computers and the 
internet and, in light of the study findings above, it is clear that even when there is some access, inadequate ICT infrastructure, malfunctioning ICT devices, teachers' attitudes to the use of technology, their incompetence, and their general unpreparedness along with theft and vandalism perpetuate the digital divide. These scholars have also pointed out that the lockdown plans for teaching and learning have not adequately prevented losses in learning for learners who do not have access to educational technology at home.

The lockdown following the Covid-19 outbreak revealed how deep the digital divide is in certain schools and communities. As indicated above, the digital divide at disadvantaged schools means that teachers and learners in these quintile 1 schools cannot have remote classes during the Covid-19 lockdown.

Rolling out ICT infrastructure to some teachers and learners and not to others created a material access gap in schools. The GDE started rolling out tablets to Grade 12 learners only, hence smartboards were mostly in Grade 12 classrooms although some were in Grade 11 classrooms. Some Grade 12 classrooms had functional smartboards. For instance, at Schools $\mathrm{B}$ and $\mathrm{C}$, teachers and learners were able to use the infrastructure during teaching and learning, whereas, at School A, all smartboards had stopped working by the time this study was conducted. Some Grade 11 teachers at the three schools studied were also given laptops by the GDE but some of the laptops were not functioning properly. Internet connectivity was confined to the administration blocks of the three schools. This confirms the findings of the National Education Infrastructure Management System (NEIMS) that only 20\% of schools in South Africa - the elite ones - have internet access for teaching and learning, as Parker et al. (2020) have noted. Although the GDE's rollout of ICT to schools was inadequate according to our research, this was exacerbated by theft and vandalism of the infrastructure.

According to van Dijk's (2008) model, material access means accessibility to ICT infrastructure and the cost of the ICT devices. Our study confirms that material access is closely related to the socio-economic status of an individual, family, place, or school. So, those who had no access to ICT for teaching and learning resorted to traditional teaching methods of reliance on the chalkboard and the textbook which is now not a realistic option following the national lockdown that closed schools on 26 March 2020 as a result of the global outbreak of Covid-19. The digital divide was felt even before the Covid-19 pandemic struck given that internet connection was limited to the administration blocks at schools and this meant that teachers and learners could not connect with peers or with educational portals and could not do research online. It also meant that teachers and learners could not learn how to access and use online teaching and learning nor to practise this and the result of all this is a deepening of the digital divide.

Van Dijk (2008) argued that skills and usage access were essential conditions for competent ICT operation. It was found that most teachers had limited ICT skills; not every teacher was trained on how to use technology in the classroom thus some lacked the digital competencies regarded by UNESCO (2011) as being essential. Instead of teachers assisting learners to become collaborators, creators of knowledge, and problem solvers through the use of ICT, some teachers themselves, although supposedly trained in ICT use, "relied on learners 
whenever they failed to operate" the ICT devices or failed to log on to the internet. This confirms van der Berg \& Spaull's (2020) argument that most teachers in South African schools lack adequate ICT skills. Those who were trained need more training since the training received was, quite clearly, inadequate. For example, some supposedly trained teachers lacked the confidence to use ICT in the classroom or remotely. This is in line with findings by Marongwe et al. (2019) that teachers need more training, and that one-size-fits-all training should be avoided. Limited digital skills, which, at best, were what some teachers had, are a limiting factor to the fruitful undertaking of certain online tasks and this further increases the digital divide among the schools that have and those that do not have the infrastructure and the skills.

Selwyn (2006) noted that inasmuch as the material access was increasing for many people, second level divides in skills and usage patterns were becoming more pronounced. Chigona (2018) found that teachers in Western Cape schools also required more ICT training to ensure their effective use of technology in their classrooms. Such limited digital skills might result in some teachers and learners abandoning the technology which is very useful in these unprecedented times in which we are living given the Covid-19 pandemic.

In our study we found that the conditions of the available ICT infrastructure deterred most teachers from using the technology. The few tablets that were given to some learners broke easily and laptops that were given to some teachers were malfunctioning. All this, compounded by the lack of access to the internet and being unable to afford buying data, frustrated and demotivated some teachers and learners.

The school principals who participated in the study articulated clearly that some teachers were afraid of using ICT in teaching and learning. It emerged from our study that such an attitude on the part of some teachers towards the use of ICT contributed to the deepening digital divide at schools, especially during the Covid-19 outbreak. Some seasoned teachers felt that they were too old to be taught how to use ICT in the classroom or for remote teaching. This finding concurred with those of Spelman and Marongwe (2018) and van Dijk (2005) who found out that mental factors also affect motivational access to ICT. It can thus be argued that those experienced teachers were what van Dijk and Hacker (2003, p. 4) called technology "want nots." Furthermore, in line with what Marongwe et al. (2019) established, teachers' attitudes towards ICT predicted their use of the technology, or lack of it, in the classroom. Some seasoned teachers preferred using the chalkboard and the textbook (which was impossible during the Covid-19 pandemic because of the lockdown restrictions pertaining to physical distancing) to using ICT. This automatically implies that learners taught by such teachers will not be exposed to ICT use in their learning and will lag behind while others are progressing. The older seasoned teachers believed that the young teachers from colleges and/or universities were the ones who could use ICT in teaching and learning.

The schools studied are situated in poor communities where theft is commonplace and such theft obviously also has an impact on the material access to ICT for learning. Van Dijk (2008) stated that material access refers to physical access of ICTs that can be accessed at institutions of learning, homes, and public places. There are, however, inequalities to physical 
access as a consequence of disparities to access conditions, access points, and types of hardware among other things. The ICT devices at the schools were often stolen and the infrastructure frequently vandalised. For example, electric cables which connected smartboards to the power supply were stolen and so were the routers. Computers were stolen so cyber laboratories were empty at the three schools. Teachers and learners were experiencing the same acts of theft and vandalism at home, too. Tablets were stolen from learners in the community. From this study it is evident that the digital divide is deepening at disadvantaged secondary schools. Thefts also occurred when schools were closed during the lockdown and more than 408 schools have been vandalised in South Africa (SABC 404, 2020). The Department of Education spokesperson Elijah Mlanga stated that such barbaric acts of targeting and vandalising schools was worrying, and these acts left the Minister of Basic Education, Angie Motshekga, shocked.

\section{Recommendations}

We recommend that the Department of Basic Education provide adequate ICT infrastructure at schools, including access to the internet which is essential for online learning. The issue of security also has to be addressed. All teachers should be continually motivated and trained on how to use technology in the teaching of their various subjects. This would help in these uncertain times of Covid-19 because online learning and teaching could happen if teachers and learners were trained to use ICT effectively. Furthermore, all learners should be provided with ICT devices such as tablets and computers and should receive subsidised data.

Awareness campaigns on the advantages of using ICT in schools should be carried out in the communities where schools are located. Such schools could then be benefitting from online classes during the national lockdown period. If the communities take ownership of the schools, this might curb the theft of ICT infrastructural items and devices from them.

\section{Conclusion}

We conclude that intrinsic factors such as negative attitudes towards ICT and extrinsic factors such as inadequate ICT infrastructure in these three schools create digital, information, and knowledge divides at them. This confirms what the access model by van Dijk (2008) addresses. Although the data was collected before the outbreak of the Covid-19 pandemic the findings are still relevant to what many quintile 1 schools are experiencing. The schools in this study cannot run online classes when schools are closed during lockdowns. We conclude that the outbreak of Covid-19 in 2020 just worsened the existing problems and exposed the inequalities that have existed and continue to exist in schools.

\section{References}

Adegbenro, J. B., Gumbo, M. T., \& Olakanmi, E. E. (2017). In-service secondary school teachers' technology integration needs in an ICT enhanced classroom. The Turkish Online Journal of Educational Technology, 16(3), 79-87. 
Baxter, P., \& Jack, S. (2008). Qualitative case study methodology: Study design and implementation for novice researchers. The Qualitative Report, 13(4), 544-559.

Benali, M., Kaddouri, M., \& Azzimani, T. (2018). Digital competence of Moroccan teachers of English. International Journal of Education and Development using Information and Communication Technology (IJEDICT), 14(2), 99-120.

Chen, B. (2015). Exploring the digital divide: The use of digital technologies in Ontario public schools. Canadian Journal of Learning and Teaching, 41(3), 1-22.

Chigona, A. (2018). Digital fluency: Necessary competence for teaching and learning in connected classrooms. The African Journal of Information Systems, 10(4), article 7. https://digitalcommons.kennesaw.edu/ajis/vol10/iss4/7

Chigona, A., \& Chigona, W. (2010). An investigation of factors affecting the use of ICT for teaching in the Western Cape schools. Proceedings of the 18th European Conference on Information Systems, 61, 1-12. https://aisel.aisnet.org/ecis2010/61

Chirwa, M. (2018). Access and use of internet in teaching and learning at two selected teachers' colleges in Tanzania. International Journal of Education and Development using Information and Communication Technology (IJEDICT), 14(2), 4-16.

Chisango, G. (2019). The adoption and use of information and communication technologies (ICTs) in teaching and learning at township secondary schools in Sedibeng West District Municipality (Unpublished doctoral dissertation). University of South Africa, Pretoria, RSA.

http://uir.unisa.ac.za/bitstream/handle/10500/26294/thesis_chisango_g.pdf?sequence= $1 \&$ isAllowed $=\mathrm{y}$

Chisango, G., \& Marongwe, N. (2018). The impact of inadequate information and communication technologies on teaching and learning of pre-service teachers at a rural university in South Africa. J Communication, 9(1/2), 1-10. https://doi.org/11.258359/KRE-31.

Chisango, G., Marongwe, N., Mtsi, N., \& Matyedi, T. E. (2019). Teachers' perceptions of adopting information and communication technologies in teaching and learning at rural secondary schools in Eastern Cape, South Africa. Africa Education Review http://www.tandfonline.com/raer20 https://doi.org/10.1080/18146627.2018.1491317 ISSN 1753-5921 (Online), ISSN 1814-6627 (c) Unisa Press 2019.

DeBell, M., \& Chapman, C. (2006). Computer and internet use by students in 2003 (NCES 2006-065). National Center for Education Statistics.

Du Plessis, A., \& Webb, P. (2012). Teachers' perceptions about their own and their schools' readiness for computer implementations: A South African case study. The Turkish Online Journal of Educational Technology, 11(3), 312-325. 
Ercikan, K., Asil, M., \& Grover, R. (2018). Digital divide: A critical context for digitally based assessments. Education Policy Analysis Archives, 26(51), 1-24.

Hohlfeld, T. N., Ritzhaupt, A. D., Barron, A. E., \& Kemker, K. (2008). Examining the digital divide in K-12 public schools: Four-year trends for supporting ICT literacy in Florida. Computers and Education, 51(4), 1648-1663.

Harrison, H., Birks, M., \& Mills, J. (2017). Case study research: Foundations and methodological orientations. Forum Qualitative Sozialforschung / Forum: Qualitative Social Research, 18(1), Art. 19. http://nbn-resolving.de/urn:nbn:de:0114-fqs1701195

Hsu, S. (2010). The relationship between teacher's technology-integration ability and usage. Journal of Educational Computing Research, 43(3), 309-325.

Inan, F. A., \& Lowther, D. L. (2010). Factors affecting technology integration in K-12 classrooms: A path model. Education Technology Research and Development, 58(2), 137-154.

Isaacs, S. (2007). Survey of ICT and education in Africa: South Africa country report. http://www.infodev.org/infodev-files/resource/InfodevDocuments_429.pdf

Katz, J. E., \& Rice, R. E. (2002). Social consequences of internet use, access, involvement and interaction. MIT Press.

Marongwe, N., Munienge, M., \& Chisango, G. (2019, July). Can a solution be found using information and communication technology gadgets in higher education? A case of a rural university. Paper presented at EDULEARN19, 11th International Conference on Education and New Learning Technologies, Palma, Spain.

Mhlanga, E. 2020. (SABC 404, 2020). Minister of Basic Education, Angie Motshekga, briefs the nation on schools reopening plan. Streamed live on 19 May 2020 at 18.03 Central African Time, Day 54 Level 4 SALockdown: Update on preparations for the reopening of schools: Future of the class of 2020. https://www.gov.za/speeches/minister-angie-motshekga-condems-vandalisingschools-during-coronavirus-covid-19-lockdown

Mishra, L. (2016). Focus group discussion in qualitative research. TechnoLEARN, 6(1), 1-5.

Molefe, K., Meyer, N., \& de Jongh, J. (2018). A Comparative analysis of the socio-economic challenges faced by SMMEs: The case of the Emfuleni and Midvaal Local Municipal areas. Journal of Economics and Behavioral Studies, 10(4),7-21.

Motshekga, A. (2020). Minister Angie Motshekga on Basic Education Sector Plans to support learners during Coronavirus COVID-19 lockdown. Media briefing on the plans the Council of Education Ministers had. https://www.gov.za/speeches/ministerangie-motshekga-basic-education-sector-plans-support-learners-during-covid-19. 
Njilo, N. (2020). All students must get fair chance to finish academic year: Buti Manamela. Sunday Times, 03 June. https://www.timeslive.co.za/politics/2020-06-03-all-studentsmust-get-fair-chance-to-finish-academic-year-buti-manamela/

O’Keeffe, J., Buytaert, W., Mijic, A., Brozovic, \& Sinha, R. (2016). The use of semistructured interviews for the characterisation of farmer irrigation practices. Hydrology and Earth Systems Sciences, 20,1911-1924.

Palak, D., \& Walls, R. T. (2009). Teachers' beliefs and technology practices: A mixedmethods approach. Journal of Research on Technology in Education, 41, 157-181.

Parker, R., Morris, K., \& Hofmeyr, J. (2020). Education, inequality and innovation in the time of COVID-19. Johannesburg: JET Education Services.

Sáncheza, A., Marcosb, J. M, Gonzáleza, M., \& GuanLina, H. (2012). In-service teachers' attitudes towards the use of ICT in the classroom. Procedia - Social and Behavioral Sciences, 46, 1358-1364.

Selwyn, N. (2006). Digital division or digital decision? A study of non-users and low-users of computers. Poetics, 34(4/5), 273-292. https://doi.org/10.1016/j.poetic.2006.05.003

Semerci, A., \& Aydın, M. K. (2018). Examining high school teachers' attitudes towards ICT use in education. International Journal of Progressive Education, 14(2), 93-105.

Seraji, N. E., Ziabari, R. S., \& Rokni, S. J. A. (2017). Teacher's attitudes towards educational technology in English language institutes. International Journal of English Linguistics, 7(2), 176-185.

Shan Fu, J. (2013). ICT in education: A critical literature review and its implications. National Institute of Education, Singapore. International Journal of Education and Development using Information and Communication Technology (IJEDICT), 9(1), $112-125$.

South African Government News Agency. (2016, August 22). Progress made in ICT roll out in Gauteng schools. https://www.sanews.gov.za/south-africa/progress-made-ict-rollout-gauteng-schools

South African Government. (2015). Gauteng infrastructure on roll-out of paperless classroom system. https://www.gov.za/speeches/gauteng-infrastructure-roll-outpaperless-classroom-system-21-jul-2015-0000

South Africa. Department of Education Government Gazette. (2004). Draft White Paper on e-education: transforming learning and teaching through information and communication technologies (ICTs). Vol. 407 No. 267734. http://www.gov.za/documents/white-papers 
Spelman, K., \& Marongwe, N. (2018). Technophobia: Understanding computer anxiety for teaching and learning of Computer Studies. J Communication, 9(1/2), 11-23. https://doi.org/11.258359/KRE-32.

Tsetsi, E., \& Rains, S. A. (2017). Smartphone internet access and use: extending the digital divide and usage gap. Mobile Media \& Communication, 5(3), 239-255.

UNESCO. (2011). UNESCO ICT Competency framework for teachers. http://unesdoc.unesco.org/images/0021/002134/213475e.pdf

van der Berg, S., \& Spaull, N. (2020). Counting the cost: COVID-19 school closures in South Africa \& its impacts on children. Research on Socioeconomic Policy (RESEP). Stellenbosch University, Stellenbosch.

van Deursen, A., \& van Dijk, J. (2018). The first-level digital divide shifts from inequalities in physical access to inequalities in material access. New Media \& Society, 21(2), 354-375.

Van Dijk, Jan A. G. M., \& Hacker, K. (2003). The digital divide as a complex and dynamic phenomenon. Information Society, 19, 315 -326. http://doi.org/10.1080/01972240309487

van Dijk, J. A. G. M. (2005). The deepening divide: Inequality in the information society. California: Sage.

Van Dijk, J. (2008). The handbook of internet politics. London: Routledge.

van Dyk, H., \& White, C. J. (2019). Theory and practice of the quintile ranking of schools in South Africa: A financial management perspective. South African Journal of Education, 39(1), 1-9.

Wellington, J. (2015). Educational research: Contemporary issues and practical approaches. Bloomsbury Publishing. https://books.google.ie/books?id=SHYeBQAAQBAJ\&printsec=frontcover\&source $=\mathrm{g}$ bs_ge_summary_r\&cad $=0 \# \mathrm{v}=$ onepage $\& \mathrm{q} \& \mathrm{f}=$ false

Zhong, Z. J. (2011). From access to usage: The divide of self-reported digital skills among adolescents. Computers and Education, 56(3), 736-746. 